2010

\title{
Understanding Criminal Law Through the Lens of Reason
}

François Tanguay-Renaud

Osgoode Hall Law School of York University, FTanguay-Renaud@osgoode.yorku.ca

Follow this and additional works at: http://digitalcommons.osgoode.yorku.ca/all_papers

\section{Repository Citation}

Tanguay-Renaud, François, "Understanding Criminal Law Through the Lens of Reason" (2010). All Papers. Paper 1.

http://digitalcommons.osgoode.yorku.ca/all_papers/1 


\section{UNDERSTANDING CRIMINAL LAW THROUGH THE LENS OF REASON}

Gardner, John. 2007. Offences and Defences: Selected Essays in the Philosophy of Law. Oxford: Oxford University Press, 288pp.

\section{François Tanguay-Renaud*}

In 1968, H.L.A. Hart, who was then in his last year as Professor of Jurisprudence at the University of Oxford, published a collection of his past essays on criminal law theory which he complemented with a postscript (Hart 1968). Four decades later, his most recent successor in title, John Gardner, offers us a similarly organised compilation-Offences and Defences: Selected Essays in the Philosophy of Criminal Law-in which a Reply to Critics is substituted for the postscript. Hart's collection is widely acknowledged as one of his foremost contributions to the philosophy of law and, to this day, remains one of the foundational texts in criminal law theory. In Offences and Defences, John Gardner carries the Oxonian torch admirably in terms of both depth and innovation. He provides us with a remarkably rich, coherent and thought-provoking set of arguments that will no doubt join Hart's among the classic starting-points for philosophical inquiry about the criminal law.

I say that Gardner's collection is remarkably coherent since the arguments presented build on each other quite seamlessly, despite having been committed to print over a period of thirteen years. Perhaps even more impressively, they also cohere, by and large, with the rest of Gardner's extensive body of work. Like Hart, Gardner is a theorist of many talents who, over the last twenty years, has had much to say about many other philosophical questions-most notably, about issues in tort theory, general jurisprudence, and moral theory. The essays in Offences and Defences constitute only a segment of a larger intellectual project that seeks to theorise criminal law and tort law by understanding each in relation to the other, as well as in light of more general jurisprudential and moral insights. That this dimension of Gardner's project may not be readily apparent to a casual reader of his book is understandable, given his decision not to include a number of key essays that make some of these more holistic connections clearer (e.g., Gardner 1998, 2005). That being said, the alert eye will readily recognize Gardnerthe-exclusive-legal-positivist who argues that the criminal law 'unexcludes' otherwise purportedly cancelled reasons for actions when it grants justification defences (148). Gardner-the-liberal-perfectionist is also omnipresent, as reflected in many of his conceptual and critical takes on the internal structure, functions, and proper scope of the criminal law. However, it is Gardner-the-rationalist (and, some might add, the committed-moral-realist) who gives the collection its most distinctive tone.

Granting, like many before him, that the legitimacy of the criminal law quite centrally depends on its sensitivity to its subjects' blameworthiness (with 'fault' and 'culpability' often used as synonyms), ${ }^{1}$ Gardner defines the concept as follows: 'To be

\footnotetext{
*Assistant Professor, Osgoode Hall Law School. Thanks are owed to Victor Tadros for helpful comments.

${ }^{1}$ In Gardner's words, 'by punishing people in proportion to their crimes, where those crimes are mapped according to the action that made them wrongful adjusted for the offender's blameworthiness in respect of
} 
blameworthy,' he writes, 'one must: (a) have done something wrong and (b) have been responsible for doing it, while lacking (c) justification and (d) excuse for having done it' (227). Much of Offences and Defences consists in a conceptual elucidation of variables (a) to (d) and their interrelations. For Gardner, the criminal law story begins with wrongdoing, which he defines as an 'action in breach of duty' (253) - or, as he clarifies elsewhere, an action in breach of a reason that is both categorical and mandatory in that it '(i) does not depend for its existence on one's goals at the time, and (ii) is also a reason not to act for certain conflicting reasons' (Gardner and Macklem 2002, p. 465). This preliminary step is crucial in Gardner's thought and grounds his rejection of conceptions of 'blameworthiness at large, or blameworthiness tout court' that are solely dependent on 'how things seemed to us at the time of our action' (229-230). Wrongdoing is, at least in part, action that does not conform to reason, as assessed from an agent-neutral perspective. It is of this wrongdoing (either principal or accessorial), objectively understood, that we can then ask whether it was perpetrated by a responsible agent, and whether she had any justifications or excuses for perpetrating it. ${ }^{2}$ Of course, to be legitimate, the criminal law needs to tailor its definition of the wrongs it criminalizes: to provide its addressees with adequate guidance and warning (the 'rule of law' constraint), to prevent harm (the 'harm principle' constraint), and to conform to any other requirements that morality may impose on it in virtue of its institutional claim to authority, its characteristic resort to coercion, or otherwise. In Chapters One, Two, and Three, and in the first two sections of the Reply to Critics, Gardner has much to say about ways in which the criminal law may optimally comply with such constraints. For example, he argues that the law should endeavour to define crimes in 'action-specific' terms (55, 240-241), that textual clarity should be carefully balanced with a concern for moral clarity (43-53), and that criminal prohibitions should, at least indirectly, serve to prevent harm (proportionately and effectively) (29-32, 242). That said, these discussions are all grounded in an understanding of legitimately criminalized wrongdoing as actual wrongdoing - that is, a breach of an actual duty legitimately recognized (malum in se) or created (malum prohibitum) by the criminal law (239).

Not all variables in Gardner's account of blameworthiness (fault, culpability) are to be assessed from an exclusively agent-neutral perspective. Yet, all are to be understood

them, the court contributes decisively to the affirmation of the offender's humanity which is a sine qua non of the legitimacy of any modern State punishment' (233). As he emphasises in the postscript (282-283), it is really criminal law as a whole that he has in mind here, since, according to him, 'the criminal law is only secondarily a vehicle for [...] punishment. It is primarily a vehicle for the public identification of wrongdoing (by standards of evidence and procedure) and for responsible agents, whose wrongs have been thus identified, to answer for their wrongs by offering justifications and excuses for having committed them' (80) and, thus, establish that they are not blameworthy (faulty, culpable).

2 Gardner also speaks, without much detail or nuance, of 'fault-anticipating wrongs' that are only committed by responsible agents who lack (certain) justifications or excuses for what they do (150-153). However, since these more complex wrongs are generally parasitic on more basic 'strict wrongs' whose commission is not contingent on their perpetrator's blameworthiness, their existence does not undermine his basic categorization. Of course, I do not mean to imply here that Gardner could not usefully say more about these 'frequently'-encountered fault-anticipating wrongs. A discussion of the relationship between the various breaches of justificatory or excusatory standards that can partly constitute them and the range of mental-state requirements typically encountered in the formulation of both criminal law offences and moral wrongs would perhaps be most welcome. 
at least partly in relation to the realm of reason characterized as such. Take element (c), for example, which, for Gardner, depends in part on how things seemed to the agent at the time of action and in part on how things actually were. Wrongdoing is justifiable, Gardner argues, if the reasons in favour of it are not defeated-that is, if they are not prohibited by the criminal law in the case of criminal justifications, and are not defeated, all things considered, in the case of moral justifications (which, Gardner assumes, legal justifications ought, by and large, to reflect). However, an agent's wrongdoing is justified only if he acts for one or more of those undefeated reasons for action (95-108). ${ }^{3}$ Failing to act for such reasons tends to reflect badly upon one- - that is, it tends to constitute one's blameworthiness_-as a rational agent (and, implicitly, given the kind of reasons at stake, as a moral agent).

I say 'tends to' reflect badly upon one as a rational agent, because an agent who fails the test of justification may then retreat to element (d), the excuse element, to resist an allegation of blameworthiness. Indeed, an agent who acts wrongfully on the basis of a reasonable error in cognition or a reasonable affective distortion of his practical thinking may well not be worthy of any blame. So, here again, it matters what predicament the agent took himself to be in. However, it also matters whether there were actual undefeated reasons of a different kind-i.e., reasons for belief, for emotion, for attitude, etc.- - that made the way in which the agent interpreted his predicament reasonable (108113). Only then does it make sense to think that the agent's unjustified wrongful action should not reflect badly on him-i.e., that he is not worthy of blame - as a rational agent. True, says Gardner, any rational agent, given the choice, would rather be justified than excused. It is better to act for an undefeated reason than to be drawn, even for an undefeated reason, into acting for a defeated one. But this is not because wrongdoing while fully excused reflects badly upon one as a rational agent. For Gardner, 'the gist of an excuse' is precisely that one's action, although wrong, lived up to the expectations of reasonableness befitting the particular role(s) that the agent was playing at the time, be it that of a police officer, a soldier or, perhaps more controversially, a simple human being (121-139). The difference is that justification brings one closer than excuse to perfect success as a rational being - that is, success not only in terms of one's cognitive or emotional interpretation of the world, but also in one's practical responses to it. That said, Gardner stresses: that 'one falls short of perfect success as a rational being need not be one’s fault' if the failure does not reveal unfitness for one’s relevant role(s) (272).

This emphasis on rationality — which, to some, may seem overstated in Gardner's account of blameworthiness - takes its roots in his understanding of who, in the first place, can intelligibly be called to answer (criminally or, more generally, morally) for wrongdoing. Gardner's position, encapsulated in element (b), is that an agent must be responsible in the sense of being response-able. 'Responsibility in the basic sense,' he writes, 'is none other than an ability to offer justifications and excuses' for wrongdoing (182). It is 'the ability to explain oneself, to give an intelligible account of oneself, to

\footnotetext{
${ }^{3}$ To be sure, Gardner's account of this agent-perspectival aspect of justifications in terms of 'how things seemed to the agent at the time of action' (227) can be misleading. As his work otherwise makes clear, it is motivation and not mere perception that matters for justification. Although the two ideas are intimately related in that perception generally influences motivation, mere perception is insufficient.
} 
answer for oneself, as a rational being.' This basic ability to respond to reason must be differentiated from another sense of 'being responsible for what was done,' which means bearing the adverse normative consequences of its having been done. In fact, basic responsibility 'is normally, and certainly in any legitimate criminal court, a precondition of responsibility in [this second consequential] sense' (131). Its value is primarily intrinsic and 'is instantiated, rather than instrumentally served by, the criminal process' (188-191). It 'forms part of the case for my being responsible (accountable) to someone' (277) for wrongdoing, which, in the criminal law context, must then be complemented by the other elements of blameworthiness (alongside broader considerations of legitimacy and standing). In its absence, the criminal law, which is primarily concerned with our conformity with certain (moral) reasons, should generally refrain from even considering the possibility of blaming — be it by condemning, punishing, or any of their cognates. ${ }^{4}$

As Gardner himself acknowledges in the preface, many lines of thought advanced in the collection, including the ones just introduced, have been subject to extensive and formidable criticisms. Many such criticisms are discussed in the Reply to Critics and, despite Gardner's insistence that he has 'not had cause to disown any of the lines of thought assembled here' (vii), it soon becomes clear to the reader that a number of his arguments demand-and, often, lay valuable foundations for-further inquiry in what tend to be difficult philosophical terrains. For instance, what does it mean to act (justifiedly) for an undefeated reason? Gardner tells us that reasons are facts, but are risks facts? In response to Victor Tadros's claim that there are facts about what will happen in the future-such as objective risks-as well as facts about how the world is now, Gardner questions the very possibility of present reasons about the future. As a result, his view of justification focuses on 'present tense' cases, such that ' $D$ has a reason to run away only if he is indeed going to be attacked' (258). However, aren't many cases of justified self-defence cases where the attacker could possibly have turned away before injuring her victim, and was really only posing a risk to his life and limb, as tangible and imminent as it may have been, at the time of the defensive action? Gardner does not account for such 'future tense' cases in argument except by suggesting, in a questionbegging fashion, that they may lie on the borderline between justification and excuse. This criticism can be sharpened by noting that Gardner's own example of D who 'is going to be attacked' seems more oriented towards the future than the present. It may be that D only has a reason to run away if he is being attacked-a more clearly 'present tense' kind of case. However, when pressed, this view appears rather implausible. What if, at a given point in time, $\mathrm{D}$ is unmistakably being attacked, but the attack has no likelihood of being realized-say, because the attacker is about to be knocked unconscious by a speeding motorist? Is D justified in running away? To the extent that he is not-i.e., the more intuitive answer and the one that, all else being equal, I believe Gardner would give - it must either be because the attack will not be realized, or because, at the relevant point in time, it is too unlikely to be realized. If, as Gardner claims, justification depends on present facts, we are then back at square one, confronted with the

\footnotetext{
${ }^{4}$ The criminal law may, however, be justified in bringing non-responsible wrongdoers with mental health problems 'into contact with those who can treat their condition' (215). Insofar as the criminal law has any justification, Gardner insists, it is likely not a unitary one.
} 
daunting task of deciding whether risks are facts and, if so, how we should specify what risks there are in fact.

On a different, though related, note, it also seems as though Gardner does not take the possibility of mixed motives seriously enough. ${ }^{5}$ What if a scrupulously law-abiding self-defender is motivated to resort to proportionate force against an attacker partly for the reason that he is being attacked, but also partly because he thinks, based on previously publicised judicial decisions, that the law would not condemn or punish such behaviour? Is he justified in acting as such? Or, what if somebody engages in the traffic of hard drugs in response to a reasonable fear that his supplier will hurt him if he doesn't, but also because he thinks that the criminal law and society at large do not expect him to resist such a threat of harm? Should he be excused? Gardner's position on such matters is perhaps exceedingly clear-cut. 'To attempt to benefit from a legal excuse by being guided by it,' he writes, 'is to forfeit that excuse' (138). He also states that anyone 'who sees a justificatory legal rule for what it really is will know that it cannot in itself motivate action in accordance with it since it gives no reasons for action' (115). One wonders whether his position would remain as firm if he explicitly attended to a wider array of cases where one of the reasons relied upon is undefeated and, arguably, sufficient to justify or excuse wrongdoing, while others, such as what the law has to say about the justifications and excuses it recognizes, are not. Examples of non-legal mixed motives may help sharpen the point. What if our self-defender happened to resent his attacker and was also quite happy to injure him and give him his 'just desert' when resorting to necessary and proportionate force in self-defence? ${ }^{6}$ Or, what if the man trading drugs under duress lived up to relevant expectations of fortitude when giving in to the threat, yet was in dire financial straights and was also somewhat driven by the lure of money? I believe that, if pressed, Gardner may be willing to concede that the self-defender was justified — since he acted at least in part for an undefeated reason-and the drug dealer was at least partially excused-since he did live up to the relevant standard of fortitude applicable in the circumstances. Thus, Gardner's reluctance to extend such recognition to cases of mixed moral and legal motives in the justificatory and excusatory contexts is somewhat puzzling. In fact, his contention that mistaken but reasonable beliefs in justification ground excuses accentuates the awkwardness of his position. Consider cases in which reliance on the possibility of such an excuse makes all the difference as to whether one is willing to respond-say, in self-defence-to what reasonably seems (although one is not sure) to be an undefeated reason-say, a culpable attack-but, as it turns out, is not. Should that would-be self-defender really be denied an excuse of reasonable mistake in justification because he partially relied on it at the time of action?

\footnotetext{
${ }^{5}$ This lack of attention comes despite Gardner's recent unambiguous acknowledgement that it is possible to act for genuinely mixed motives (Gardner 2007a, p. 2620).

6 This might be one of the 'rare cases' of justification that Gardner himself alludes to when he writes: 'That people are inclined to retaliate against those who wrong them, often with good excuse but rarely with adequate justification, creates pressure for social practices which tend to take the heat out of the situation and remove some of the temptation to retaliate, eliminating in the process some of the basis for excusing those who do so' (213-214). The puzzle introduced in the text highlights the need for further exploration of the relationship between self-defence, revenge, punishment, and criminal law that Gardner begins to unearth in the passages surrounding this quotation and in the last sections of the Reply to Critics.
} 
A colleague recently suggested to me a further example that, in her view, bolstered this line of criticism. Would the police officer monitoring speed on the highway be justified in stopping one speeding motorist out of many for the reason that she dislikes the colour of his car? ${ }^{7}$ Here, the motorist's excess speed seems to justify the detention, regardless of the officer's additional motive in stopping him and regardless of the fact that one of her reasons for stopping him is provided by the law. This example is clearly interesting, but mainly, I think, for a different reason. As Gardner himself recognizes, there are special cases in which legal officials like police officers must act upon a legal rule requiring them to perform certain actions-e.g., a temporary detention, an arrest-if these actions are to count 'as fully justified in law' (116). Some critiques have recently attempted to use this apparent discrepancy in his thought to undermine his account of justification (e.g., Thorburn 2008). However, in Gardner's defence, he is careful to point out that while criminal law justifications are always permissions to act for otherwise excluded reasons, they may sometimes be combined with role-specific legal duties. Here, one could also point out that the actions of legal officials are typically bounded by an additional type of rule-i.e., power-conferring rules-that confers legal validity on some of their actions. While stopping short of clarifying this further layer of complications and addressing the multifaceted interface between criminal law and public law in Offences and Defences, Gardner at least makes sure to highlight in passing the complexity of cases of official action, leaving himself enough room to continue developing his account gradually and systematically in future work. ${ }^{8}$

This methodological remark is important. While some have criticized Gardner for leaving key issues that his work raises unaddressed, it is in fact one of the great strengths of his style of argument. Gardner's work often looks beneath the surface of philosophical puzzles and arguments that have bogged down theorists for generations. This courageous approach often yields powerful insights, but also carries with it the constant threat of derailing his trends of thought by opening interesting new paths of inquiry along the way. Fortunately, Gardner is a thinker who tends to be careful not to move too fast and ride roughshod over deep puzzles. He generally says enough to generate novel and fruitful debate and, when challenged, rarely shies away from clarifying his claims in later work. Admittedly, his Reply to Critics sometimes raises more questions than it provides answers. For example, challenges to the soundness of his conception of 'result crimes'i.e., crimes committed by making a certain causal contribution to a certain outcome-on the ground that it neglects the possibility of outcome luck are met with question marks: 'We have just been scratching the surface of the question of whether result crimes should exist,' he writes, but 'if result crimes should exist, what causal contribution must one make to the result before one commits them?' (248). Challenges to key aspects of his defence of agent-neutralism and of its implications for a sound understanding of wrongful complicity are also met with the timid concession that he 'did not mount a full defence of

\footnotetext{
${ }^{7}$ This example, brought to my attention by Kimberley Brownlee, is a variant on a scenario deployed for different purposes in Nathanson (1985).

${ }^{8}$ On this point, see his recent 'Justification under Authority'. Canadian Journal of Law and Jurisprudence (forthcoming), available online at: http://papers.ssrn.com/sol3/papers.cfm?abstract_id=1345763.
} 
this agent-neutralist view' (278). ${ }^{9}$ With Gardner, however, these gaps in argument are most likely to be indications that further work on these topics is forthcoming, along the lines of his recent discussion of the polemical claim made in Chapter Five (120-122) and reiterated without more in the Reply to Critics (258) that all conceptually-sound and legitimate excuses - including emotional excuses - must be understood in terms of the successful achievement of relevant standards of rationality. ${ }^{10}$

Thus, it seems fitting to conclude with a call for further elaboration on one of the important conundrums as yet ignored by critics, discussants, and reviewers of Gardner's work. As I noted above, at the root of Gardner's conception of blameworthiness lies the idea of responsibility qua response-ability for one's wrongs. Without it, assessments of blameworthiness cannot even get off the ground. Gardner insists that responsibility in this basic sense has a primarily intrinsic value: it is 'a distinctively human capacity' and one whose affirmation and recognition 'is central to all distinctively human lives' (276). The point I wish to make here is that, as intuitively plausible as it may seem, this way of understanding basic responsibility and its importance fails to account for corporate action and responsibility_oft-encountered ideas in both criminal law and moral realms.

Some theorists — of whom Philip Pettit is perhaps the most sophisticated-offer spirited defences of the claim that corporate agents can be irreducibly responsible (qua response-able) for their wrongs. ${ }^{11}$ To be sure, Pettit argues, quite persuasively, that any sound account of irreducibly responsible group agents must recognize that all their matter and energy is derived from what their individual human members supply. Such group agents, insofar as there are any, are not ontologically distinct creatures, and should not be mysteriously theorized as such. Such recognition would allow Gardner, were he to go down this argumentative path, ${ }^{12}$ to preserve his idea of basic responsibility as a distinctively human capacity in the context of corporate agency, even if, in some such contexts, it could not simply be reduced to distinct human beings. That being said, it is much more debatable whether irreducible corporate responsibility, insofar as there is such a thing, can intelligibly be described as intrinsically valuable. And even if it were

\footnotetext{
${ }^{9}$ In fact, it sometimes seems as though, on the issue of agent-neutralism, Gardner's most basic assumptions are insufficiently probed. For example, he seems to think that only an agent-relativist would regard killing one person to prevent five people from being killed as wrong (58-66). However, this assumption is incorrect (e.g., Kamm 1996, ch.10).

${ }_{10}$ Gardner, John. The Logic of Excuses and the Rationality of Emotions. Journal of Value Inquiry (forthcoming), available online at: http://papers.ssrn.com/sol3/papers.cfm?abstract_id=1261764.

${ }^{11}$ For a systematic presentation of Pettit's position, see especially Pettit (2007). In short, Pettit argues that some groups acting under adequate normative frameworks are relatively autonomous agents that may be in positions to act wrongfully, have the understanding and the access to evidence required for making judgments of value, and have the control required for being able to respond appropriately to these judgments. See also French (1984).

${ }_{12}$ In a recent essay, Gardner claims that corporate organizations such as some state institutions can conceivably be agents whose agency is irreducible to the agency of their individual human members (Gardner 2007b, pp. 57-60). Of course, this claim leaves open the possibility that such irreducible corporate agents may not be rational and moral agents, but other recent comments of his seem to pre-empt this argumentative strategy. 'States,' he writes, 'are moral agents too [...] The state must not murder or be complicit in murder. It must not rape or be complicit in rape. It must not rob or be complicit in robbery' (Gardner 2007a, p. 2628). This contention seems only one short step away from the claim that states and, possibly, other corporate agents can be irreducibly responsible (qua response-able) for their wrongs.
} 
possible to make a sound case that it can intrinsically enrich human life, its primary value-just like the primary value of the corporate organizations that instantiate itwould no doubt be instrumental. For example, insofar as the idea of basic corporate responsibility is sound and, as a result, corporate entities can be worthy of blame for their wrongdoing, the criminal law might then legitimately be able to hold them consequentially responsible when all human beings involved are excused (say, because of the uneven flow of information throughout the organization) or too remotely connected to the wrong(s) in question. The intuition underlying this premise of instrumentality is powerful: an assertion of basic corporate responsibility differs significantly from an individual's affirmation of her humanity through an assertion of her basic ability to respond to reason. For one, such an assertion is unavoidably relational-a dimension which Gardner emphatically excludes from his understanding of basic individual responsibility (164-166). Yet, to the extent that some corporate agents have the irreducible ability to respond appropriately to reason, they may be said to be basically responsible in a non-negligible sense that Gardner would need to explain.

Since, as we have seen, Gardner thinks that an agent's blameworthiness is partly constituted by the agent's basic responsibility, he would then also need to explain how the differences between individual and corporate basic responsibility affect his conception of blameworthiness - a conception which, in Offences and Defences, he presents as unitary. Along similar lines, one may wonder whether irreducibly responsible corporate agents could offer excuses for wrongdoing like their individual counterparts, given their lack of self-interest, affective experience, and so forth. Here, it is noteworthy that Gardner admits in Chapter Eight that sound claims of individual excuses may vary depending on the 'social milieu' in relation to which they are made (159-162). He also appreciates that the contours of the roles that shape excusatory standards may be at least partly socially contingent (167-172). Thus, he recognizes that individual excuses have at least some 'collective' dimensions. He may even be ready to grant that such dimensions can be accentuated in the context of more formally constituted corporate organizations. However, it remains to be seen whether he would be willing to defend the possibility of irreducibly corporate excuses.

Of course, Gardner may seek to avoid such difficult questions by arguing that basic corporate responsibility is merely a useful fiction that, at times, may be justifiedly invoked by or outside the law. ${ }^{13}$ In other words, he may argue that corporations can only be held consequentially responsible for the wrongs for which others-namely, specific individuals - are basically responsible, through the operation of fictions of identification or vicarious responsibility. This position would also need to be defended since it is unclear what might justify such fictions in light of the traditional criminal law disdain for fictions of blameworthiness, and of the possibility that corporate wrongs for which no

\footnotetext{
${ }^{13}$ He seems to recognize the appeal of this other line of argument in some of his recent work. 'One must be basically responsible,' he writes, 'or at least assumed to be basically responsible, for the question of one's consequential responsibility to arise in the first place.' Why use these words? A few paragraphs later, he provides the reader with a clue by asking the following: 'Aren't there cases in which a fiction of basic responsibility may, with moral propriety, be sustained in the law (or in other institutional settings), so that the advertised precondition of consequential responsibility may be treated as satisfied when it is really not?' (Gardner 2008, p. 138).
} 
distinct individual is blameworthy may then go unaddressed by the criminal law. So there is no easy way out for Gardner. In fact, here again, his conception of blameworthiness would need to be revised accordingly and, once more, this revision would need to address whether excuses and justifications could legitimately be attributed to corporate agents (by means of fiction).

If I mention such possible lines of inquiry that transcend somewhat those of the book, yet clearly find their roots in it, it is partly to emphasize the further promise of the innovative seeds that Gardner has sown therein. This is an important point that both critics and reviewers of Offences and Defences tend to make, either explicitly or implicitly, when engaging with the rich variety of topics covered in the collection. ${ }^{14}$ Thus, while H.L.A. Hart did not contribute much to the philosophy of criminal law after the publication of his essays in Punishment and Responsibility, the future of criminal law theory is only brighter for the fact that John Gardner's thought-provoking compilation came so early in his career, and that he seems committed to build on this impressive effort.

\section{REFERENCES}

Brownlee, Kimberley. 2009. Book Review. Ethics 119(3): 561-566.

French, Peter. 1984. Collective and Corporate Responsibility. New York: Columbia University Press.

Gardner, John. 2008. Hart and Feinberg on Responsibility. In The Legacy of H.L.A. Hart: Legal, Political, and Moral Philosophy, eds. Matthew H. Kramer, Claire Grant, Ben Colburn and Antony Hatzistavrou, 121-140, Oxford: Oxford University Press.

Gardner, John. 2007a. Prohibiting Immoralities. Cardozo Law Review 28(6): 2613-2628.

Gardner, John. 2007b. Some Types of Law. In Common Law Theory, ed. Douglas E. Edlin, 51-77. Cambridge: Cambridge University Press.

Gardner, John. 2005. Wrongs and Faults. Review of Metaphysics 59(1): 95-132.

Gardner, John and Macklem, Timothy. 2002. Reasons. In The Oxford Handbook of Jurisprudence and Philosophy of Law, eds. John Coleman and Scott Shapiro, 440475. Oxford: Oxford University Press.

Gardner, John. 1998. On the General Part of the Criminal Law. In Philosophy and the Criminal Law: Principle and Critique, ed. R.A. Duff, 205-256. Cambridge: Cambridge University Press.

Hart, H.L.A. 1968. Punishment and Responsibility: Essays in the Philosophy of Law. Oxford: Oxford University Press.

Husak, Douglas. 2009. Gardner on the Philosophy of Criminal Law. Oxford Journal of Legal Studies 29(1): 169-187.

Kamm, Frances. 1986. Morality, Mortality: Volume II: Rights, Duties, and Status. Oxford: Oxford University Press.

Nathanson, Stephen. 1985. Does It Matter If the Death Penalty Is Arbitrarily Administered? Philosophy and Public Affairs 14: 149-64.

Pettit, Philip. 2007. Responsility Incorporated. Ethics 117(1): 171-201.

${ }^{14}$ I could only review a very limited portion of these topics in this note. For other interesting reviews of the book, see Husak (2009), Simester (2009), and Brownlee (2009). 
Draft for posting to SSRN: Published version available at 16(1) Res Publica 89 (2010)

Simester, A.P. 2009. Wrongs and Reasons. Modern Law Review 72(4): 648-668.

Thorburn, Malcolm. 2008. Justifications, Powers, and Authority. Yale Law Journal 117(6): 1070-1130. 